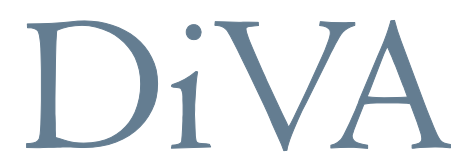

http://uu.diva-portal.org

This is an author produced version of a paper published in Technovation. This paper has been peer-reviewed but does not include the final publisher proof-corrections or journal pagination.

Citation for the published paper:

Verdegem, Pieter \& De Marez, Lieven

"Rethinking determinants of ICT acceptance: Towards an integrated and comprehensive overview"

Technovation, 2011, Vol. 31, Issue: 8, pp 411-423

URL: http://dx.doi.org/10.1016/j.technovation.2011.02.004

Access to the published version may require subscription. 


\title{
RETHINKING DETERMINANTS OF ICT ACCEPTANCE: TOWARDS AN INTEGRATED AND COMPREHENSIVE OVERVIEW
}

\author{
Pieter VERDEGEM, Ph.D. ${ }^{1,2}$, Lieven DE MAREZ, Ph.D. ${ }^{3}$ \\ ${ }^{1}$ Research Group for Media \& ICT (MICT) - Ghent University (UGent) - Interdisciplinary \\ Institute for Broadband Technology (IBBT), E-mail: Pieter.Verdegem@UGent.be \\ ${ }^{2}$ Department of Informatics and Media - Uppsala University, E-mail: \\ Pieter.Verdegem@im.uu.se \\ ${ }^{3}$ Research Group for Media \& ICT (MICT) - Ghent University (UGent) - Interdisciplinary \\ Institute for Broadband Technology (IBBT), E-mail: Lieven.DeMarez@UGent.be
}

\section{BIOGRAPHICAL NOTES}

Dr. Pieter Verdegem is a senior researcher at the Research Group for Media and ICT (MICT), Ghent University (UGent). He is also member of the Interdisciplinary Institute for Broadband Technology (IBBT). In addition, Pieter is affiliated to the Department of Informatics and Media, Uppsala University as a Postdoctoral Research Fellow. He holds a master's degree in Communication Sciences and E-communications Studies. In 2009, Pieter obtained a Ph.D. focusing on government strategies in the information society, particularly egovernment and e-inclusion. His research focuses on information society studies, ICT acceptance, critical theory and critical media and communication studies, new media \& ICT policy, e-government and e-inclusion. Pieter has published widely on these topics in scholarly journals.

Prof. Dr. Lieven De Marez has an educational background in Communication Sciences, Marketing and Statistics. The combination of interests in ICT, marketing and statistics resulted in a Ph.D. dissertation on 'The diffusion of ICT innovations, and the search for more accurate user insight in order to obtain more effective introduction strategies'. The main 
contributions made by the dissertation are the development of a new survey tool for prior-tolaunch forecasting of adoption potential for ICT innovations, and a blueprint for better introduction strategies in today's ICT environment. Currently, Lieven is a professor and senior researcher at the IBBT-MICT Research Group, where the main focus of his research is still on ICT-related user research.

\section{ACKNOWLEDGMENT}

The empirical results presented within this article are based on three research projects. The first case study is based on two IBBT research projects: ROMAS (Research on Mobile Applications \& Services) and MADUF (Maximizing DVB Usage in Flanders). Both projects are funded by IBBT (Interdisciplinary Institute for Broadband Technology) and consisted of a consortium of research groups from Ghent University (UGent), Free University Brussels (VUB) and Catholic University of Leuven (KUL). The second case study draws on a research project carried out in collaboration with Fedict, the Federal public agency for Information and Communication Technologies in Belgium. 


\section{Abstract}

In the contemporary ICT environment, we are confronted with a growing number of failing innovations. New technological innovations often fail because too much attention is still given to (technical) product-related features without taking into account the most important parameters of user acceptance. In addition, suppliers of ICT products often lack accurate insight into the distinguished profiles of their (potential) target audience. In this article theoretical considerations and empirical results on this matter are highlighted. First of all, an approach is proposed in which more traditional and often scattered vision(s) on adoption determinants are broadened into an integrated framework. The approach provides a stronger base for better targeting of (new) users of technologies. Secondly, the authors elaborate on this by rethinking these determinants with regard to later adopters. Later adopters (or even non-adopters/users) are often ignored in technology acceptance research. However, especially for policy purposes, the understanding of why people do not adopt or do not use ICT is strongly relevant in the light of the development of an inclusive information society. Both approaches are illustrated by case studies starting from a common list of nineteen ICT appropriation determinants. This framework enables to better profile both earlier and later adopters as well as it allows to formulate recommendations how to bring innovations in the market. Summarizing, this contribution offers an integrated approach on technology acceptance research by bridging the gap between a market and a policy-oriented point of view. 


\section{Introduction}

The pervasiveness of Information and Communication Technologies (ICT) and the increasing dependency on ICT in everyday life makes the study of the adoption and use of ICT a major challenge in scholarly research. In view of this, conditions for technology acceptance have always been a central pillar in all kinds of approaches of research into ICT innovations and new media technologies: ranging from diffusion theory-based approaches focusing on perceived technology characteristics since the early 60s (later extended with insights originating from social psychology models), over use and appropriation-oriented theoretical approaches since the 80s to more industry-oriented studies and approaches focusing on image and network-related determinants in the last decade (Lievrouw, 2006; Venkatesh, 2006). Multidisciplinary research on this has resulted in a cluttered list of models and determinants (Williams, Dwivedi, Lal \& Schwarz, 2009).

In the contemporary and rapidly evolving ICT environment, a comprehensive framework for understanding determinants or conditions for technology acceptance is more than ever needed. This is crucial in order to obtain the necessary insights to face the challenges of ICT managers, policymakers as well as researchers (Burgelman, 2000). Due to the exponentially increased offer of ICT innovations - and by consequence also more technologies that fail to acquire mass market potential - all stakeholders involved are desperately seeking for accurate insights into adoption determinants as a basis for more effective introduction and targeting strategies (Chen, Gillenson, \& Sherrel, 2002; Lin, 1998; Talukdar, Sudhir, \& Ainslie, 2002; Venkatesh, Morris, Davis, \& Davis, 2003; Ziamou, 2002). In addition, from a policy point of view profound insights into drivers and barriers for adoption and use of ICT are necessary in order to set up inclusive information society policies (Chaudhuri, Flamm, \& Horrigan, 2005; Milner, 2006; Rogers, 2001; Trkman, Blazic, \& Turk, 2008; van Dijk, 2005).

In this article, a framework is introduced that could help to refine our thinking on this. Firstly, the scope on adoption determinants is broadened by integrating the existing but 
fragmented approaches into a more comprehensive one. This becomes increasingly important for industrial and marketing purposes, as a thorough understanding of the needs of the user - as a customer - is necessary for acceptance of technology. Secondly, the framework has been elaborated by scrutinizing approaches that go beyond adoption diffusion. More specifically, policymakers are seeking to better understand the processes of (non-)adoption and the parameters that have an influence on the impact of ICT acceptance and use. In-depth knowledge on this is important with regard to formulating effective measures aiming to diminish the so-called digital divide. Given the rapid evolutions in ICT landscape, a 'one size fits all' approach seems to be no longer sufficient. In response of this, customized strategies grow in importance. In this perspective, however, traditional strategies only focus on the most innovative segments of the market (i.e. early adopters and innovators). The presented framework allows to gather insights into the profiles of both earlier and later adopters of ICT innovations. In sum, the envisioned comprehensive technology acceptance model supports innovation research from a double perspective: both a market and policy-oriented perspective.

This article is organized as follows. In the first part theoretical reflections on existing determinant models and approaches are briefly discussed. In addition, an integrated and comprehensive model is proposed by the authors. The second part of the article draws on the application of this framework as it is illustrated how the model has empirically been used in market and policy-oriented analysis. The last part aims to conclude by discussing the presented framework, by formulating recommendations for business as well as policy, and by highlighting emerging issues for future research in this field.

\section{Determinants for technology acceptance}

\subsection{Broadening the scope on adoption determinants}

With 'adoption determinants' we refer to parameters that influence technology acceptance in terms of the actual adoption decision (De Marez, 2006; Frambach \& Schillewaert, 2002; Venkatesh \& Brown, 2001). For a long time and mainly influenced by the 
dominant technological deterministic paradigm (Lievrouw, 2006), demographic variables were supposed to have an important influence on that adoption decision (Rogers, 2003). However, many scholars have stated that this view should be extended to an approach based on 'attitudinal' adoption determinants (Atkin, Neuendorf, Jeffers, \& Skalski, 2003; Leung, 1998; Plouffe, Vandenbosch, \& Hulland, 2001). Attitudinal determinants are related with subjective perceptions of innovation characteristics and personality traits (Bobbit \& Dabholkar, 2001).

The approach of these attitudinal adoption determinants was mainly inspired by diffusion theory (Rogers, 2003), in which innovations were supposed to have a set of five characteristics ('relative advantage', 'complexity', 'compatibility', 'trialability' and 'observability') determining the subjective perception of an individual's attitude towards the technology as well as his/her innovativeness or timing of adoption decision. The perception of each of these characteristics is assumed to have a strong relationship with the innovativeness of an individual. Innovators and early adopters, for example, are assumed to have a higher perception of relative advantage than the late majority segments (in Rogers' Scurve), together with a lower perception of complexity of the innovation (contrary to the later adopters) (De Marez, 2006; Dickerson \& Gentry, 1983; Moore \& Benbasat, 1991).

Over the years, increasing attention given to these 'attitudinal' adoption determinants resulted in a considerable yet cluttered extension of the original set of five adoption determinants. The convergence with theories originating from social psychology such as Theory of Reasoned Action (TRA) (Fishbein, 1967; Fishbein \& Ajzen, 1975), (Decomposed) Theory of Planned Behaviour ((D)TPB) (Ajzen, 1991; Taylor \& Todd, 1995) and Technology Acceptance Model (TAM) (Davis, 1986; 1989) in particular led to an extremely valuable - yet fragmented - increase in research on adoption and determinant models. As a result, some scholars consider one or two extra determinants (Holak \& Lehmann, 1990), while others take into account eight (Plouffe et al, 2001), ten (Choi, Choi, Kim, \& Yu, 2003) or more determinants (Williams et al, 2009; Wirth, von Pape, \& Karnowski, 2008). 
Downside of this increased attention is that researchers are confronted with a lack of overview, since the growing multidisciplinary interest entails a cluttered and inconveniently arranged entirety of determinants (Moore \& Benbasat, 1991; Premkumar \& Bhattacherjee, 2008). Evidently, more accurate knowledge into adoption determinants requires an insight in more than the five determinants of Rogers' diffusion theory, but it remains unclear how many and which determinants should be taken into account. Until now, a general accepted overview of (potentially) relevant adoption determinants for ICT innovations is still lacking (Busselle, Reagan, Pinkleton, \& Jackson, 1999; Hadjimanolis, 2003).

An exception is the Unified Theory of Acceptance and Use of Technology (UTAUT), developed by Venkatesh et al (2003). The UTAUT model is based on an extensive study in which different theoretical frameworks are thoroughly reviewed. Constructs originating from Theory of Reasoned Action (TRA), Technology Acceptance Model (TAM), Motivational Model (MM), Theory of Planned Behaviour (TPB), Combined TAM and TPB (C-TAM-TPB), Model of PC Utilization (MPCU), Innovation Diffusion Theory (IDT) and Social Cognitive Theory (SCT) have been empirically validated. This analysis resulted in the formulation of UTAUT, illustrated by Figure 1.

$<$ Insert Figure 1>

Figure 1: Research model of UTAUT (Venkatesh et al, 2003)

The UTAUT model drops the monolithic attitude construct in comparison with theories such as TRA, TPB and TAM. Instead, attitudinal constructs such as 'performance expectancy', 'effort expectancy' as well as 'social influence' are supposed to directly influence the behavioural intention, while 'facilitating conditions' is supposed to have a direct impact on the use behaviour. The impact of each of these constructs is mediated by two socio-demographic parameters (gender and age) and two parameters related to ICT use (experience and voluntariness of use). Finally, and similar to the models originating from social psychology, UTAUT considers the behavioural intention as the nearest proxy for the use behaviour. 
Although this comprehensive UTAUT model manages to explain more of the variance in terms of ICT use, its main added value lies in the theoretical and empirical relevance. As the founders indicate themselves, UTAUT should be seen as a basis for further empirical analysis (Venkatesh et al, 2003). A critical evaluation of UTAUT, however, could raise questions whether the proposed framework allows to provide accurate insights in both the adoption and the use decision of end-users of ICT applications. Besides challenges of investigating its applicability for different kinds of technologies and use contexts (e.g. work and/or domestic environment), it also needs further examination how UTAUT can help in exploring different profiles of (non-)adopters/users of ICT. In addition, it should also be tested if the UTAUT model allows a decomposition that is detailed enough to feed more accurate targeting approaches of potential adopter segments in marketing strategies as well as nonadopter/user profiles in policy strategies.

The framework presented within this article aims to provide a complementary contribution such as UTAUT. At the same time, however, it aims to go a step further than UTAUT, especially on the aspects that are mentioned above. More specifically, the integrated framework has the following ambitions: (1) it should allow to simultaneously investigate the adoption and use of ICT technologies; (2) it is supposed to be helpful for different innovations and contexts; (3) it should manage to differentiate between distinguished segments of the population (both within earlier and later adopters) and, (4) research based on this framework must enable to provide adequate insights with regard to effective introduction strategies/campaigns.

Unlike UTAUT and other theoretical frameworks such as TRA, TPB and TAM, our model distinguishes three categories of determinants: marketing strategy, innovation related characteristics and adopter related characteristics (De Marez, 2006). These three groups of determinants entail an influence on the behavioural intention to adopt, while the latter has an impact on innovativeness in terms of actual behaviour (adoption). However, between intention and actual behaviour, both macro and meso aspects may determine the actual 
behaviour decision of an individual. Figure 2 depicts the basic conceptual model behind this framework.

<Insert Figure 2>

Figure 2: Basic theoretical model (De Marez, 2006)

Comparable to the development of UTAUT, a meta-analysis on determinants for ICT adoption has been conducted to feed this model (De Marez, 2006). This had a dual purpose. On the one hand, it envisioned a comprehensive overview of determinants that might influence the individual's adoption decision. Starting from an analysis of a wide range of studies and theoretical determinant frameworks (i.e. a fragmented mix of influences among which (D)TPB, TAM and diffusion theory's set of five determinants were the most recurring) this resulted - based on empirical analysis in different stages (De Marez, 2006) - in a model of nineteen determinants in which ten innovation-related characteristics (perceptions), eight adopter-related characteristics and the impact of the marketing strategy can be distinguished (see Table 1). On the other hand, as it has been the case for the theoretical models underlying this comprehensive model as well, the framework also served as the basis for translation/operationalization (for empirical goals) into a measurement instrument consisting of 47 Likert statements.

$<$ Insert Table 1>

Clearly, innovativeness and the adoption decision seem to be determined by more characteristics than the original five initiated by Rogers' diffusion theory (Rogers, 2003). The perception of 'relative advantage' for example, expresses itself in several dimensions (Moore \& Benbasat, 1991). In addition, this concept is also a central aspect in TAM ('perceived usefulness') (Davis, 1989) or in SCT ('outcome expectations') (Compeau, Higgins, \& Huff, 1999). Most scholars relegate to Rogers' work in his conceptualization of 'observability' in terms of 'perceived result demonstrability', while some others distinguish the latter from 'visibility' as the degree to which the innovation is visible to others in its own right (Van Slyke, Ilie, Lou, \& Stafford, 2007). Others stress the importance of accounting for 'perceived 
enjoyment of using the innovation (the so-called 'likeability' of ICT applications) and 'reliability' as a dimension of perceived risk that is not covered by other determinants ('reliability' in this context refers to 'performance risk'). 'Innovativeness', on the other hand, is the most important personality characteristic. It covers a multitude of sub dimensions such as 'venturesomeness', 'novelty seeking', 'cosmopolitanism', 'variety seeking', 'information seeking' (Mudd, 1990). 'Opinion leadership' needs to be considered as a separate dimension, just as the personal 'optimism' towards technology, 'product knowledge', 'willingness (and ability) to pay', 'perceived impact on one's personal image', 'perceived control, 'impact of social influences' and 'impact of marketing, advertising and promotional strategies' (De Marez, 2006).

If industry strategies nowadays require more profound insight in more than the traditional five determinants, it will largely boil down to a better understanding of these nineteen key determinants. Depending on the specific technology and/or consumer profiles, it can be expected that different subsets of these nineteen determinants will have a decisive impact on the actual adoption decision. If prior-to-launch research now could reveal which determinants are the most important drivers and barriers for distinguished segments of adopters/users (including different technologies and/or contexts), this would allow to adjust and optimize the (targeting) approach of these segments. Question remains, however, how to acquire such prior-to-launch insights? The empirical part of this article elaborates on this by providing some examples of empirical research on this matter.

Besides the need for accurate measurement scales supporting industrial or commercial purposes, also policymakers are exploring strategies to realize their public goals. In the past, tools for policy research have largely differed from those of industry. More recently, however, initiatives are undertaken to enhance a better collaboration between public and private players, especially in the ICT and innovation landscape (Chesbourgh, 2003; Chesbourgh, Vanhaverbeke, \& West, 2006). The rise of concepts such as public-private partnerships, open innovation, etc. clearly illustrate this trend. In light of this, one could argue that research frameworks should simultaneously take into account industrial and societal values and goals. 
Therefore, it has been investigated up to which degree the presented model can be elaborated towards a later adopter/non-user focus as well.

\subsection{Extending the early adopter focus: What about later adopters and non-users?}

Another challenge of research regarding the acceptance of new technologies especially in view of strategies that go beyond a market approach - is how to gain insight into the profiles of later/non-adopters. Innovation studies have traditionally paid relatively less attention to phenomena such as non-use or rejection of the technology (Roe \& Broos, 2005; Selwyn, 2004; Wyatt, 2005). People who step later in the innovation circle or even resist to do this, are often left aside. However, research of later/non adoption can also offer significant added value. Firstly, for industry or ICT managers a more accurate insight in the motivations why (not) to adopt a technology, would enable them to adjust and tailor the innovation (in all its dimensions: the product itself but also distribution and communication aspects) in order to stimulate appropriation by a larger part of potential customers and even the overall population. Secondly, for policymakers coping with policies that prevent exclusion of groups of citizens in the information society, insights into the parameters of adoption/rejection by later or non-adopters are of crucial importance to tailor their approach to these target audiences (Rogers, 2001).

The adoption of a technology (as for which the determinants are discussed above) cannot be the sole focus when studying the factors that influence technology acceptance. This would be too much a technology deterministic, mainly serving 'industrial purposes' (how to approach the most interesting segments of innovators, early adopters, early majority as good and as soon as possible?) (Rogers, 2001). Consequently, a more elaborated focus on technology acceptance not only requires a focus on adoption but also on use determinants (Eriksson \& Nilsson, 2007; Karahanna, Straub, \& Chervany, 1999). In addition, a thorough understanding of technology acceptance not only asks for a focus on the first segments in the diffusion curve, but also on the later segments in that curve (late majority and laggards) 
(Selwyn, 2006; van Dijk \& Hacker, 2003; Verdegem, 2009). This also relates to the so-called 'pro-innovation bias' criticism on Rogers' diffusion theory, namely the assumption that every technology will eventually be accepted by all members of the envisioned social system. Several scholars (e.g. van Dijk, 2005) point to this for rejecting the S-curve as a central idea within diffusion theory.

Attention for differences in access to and use of digital technologies in scholarly publications, in political studies as well as in the popular press and media, appears to be an obvious result of the euphoric 'cyberbole' that characterized much of the rhetoric of new technologies since the mid-80s (Gunkel, 2003). However, profound insights in why people lag behind in the acceptance of new technologies are important in view of the development of the information society for all (Norris, 2001; van Dijk, 2005; Warschauer, 2003). In addition, as traditional strategies and policies may no longer be appropriate to reach the undiscovered parts of society, new approaches seem to be indispensable. This is most probably so in societies where a majority of people is already connected to the Internet. Thus, policymakers as well as other stakeholders involved, also need insights in the most important drivers and barriers that have an impact on the individual's decision to appropriate an ICT product (Burgelman, 2000).

Starting from a common conceptual framework (as explained above), an exploration was carried out how this framework could serve as the starting point for both investigating adoption and use determinants, with the aim to simultaneously better support market and societal policy strategies. The following section reports on the empirical application of the framework, in the case of the search for more accurate (commercial) targeting and launch strategies (3.1) and how the framework was used to inspire policymakers for the development of the information society policies (3.2). 


\section{Field experience: Results of empirical research}

\subsection{A better insight in adoption potential for industrial and marketing purposes}

The above-mentioned framework to gain in-depth knowledge on user needs and preferences has been applied and validated in a number of research projects. Two case studies are illustrated in this part of the article. Both studies were set up to acquire the necessary insights in attitudinal adoption determinants for two 'mobile innovations', in preparation for their commercial launch in Belgium. In the first case study (2006) a representative sample of 269 respondents was questioned about their attitudes towards a new 'mobile news' application in the context of the project ROMAS (funded by the IBBT, the Interdisciplinary Institute for Broadband Technology). In the second case study (2007), a representative Flemish sample (Flanders is the northern part of Belgium, home of the Dutch speaking community) of 405 respondents was questioned about their attitudes towards mobile television services. In the first study, data were collected by means of an online survey (after a two months period during which the respondents could test the mobile news application). In the second study, data were collected by means of 40 minutes during CAPI (Computer Assisted Personal Interviewing) interviews. During these interviews the respondents were shown short movies on DVD in order to familiarize them with mobile television applications and use moments. In both studies potential adopter segments (innovators up to laggards) for the innovations were forecasted by means of the 'Product Specific Adoption Potential scale' (PSAP). This PSAP scale differs from 'traditional' intention survey methods by using multiple intention questions that aim to detect consistency in the answers of the respondents (De Marez \& Verleye, 2004a; 2004b). Hereby, the nineteen determinants were transformed into a battery of 47 Likert statements (cfr. Table 2), to be answered by the respondents on five-point agreement scales (varying from 1: 'l do not agree at all' to 5: 'I fully agree').

<Insert Table 2> 
The adjustment of determinants into a measurement instrument of 47 items is the combined result of desk research and qualitative research by means of focus group interviews. A first phase of desk research resulted in a long list of statements of the nineteen determinants used in other studies and models (both diffusion theory based models and social psychology based models). In addition, the long list was verified by means of four focus group interviews with the specific goal to select the best way to translate the items into statements and to make them measurable (De Marez, 2006).

All of the 269 (mobile news study) and 405 (mobile television study) respondents completed the entire questionnaire. The most important results show a striking difference between the attitudes or determinants for both innovations. This clearly illustrates the need for product specific determinant approaches, or frameworks that can be adapted towards specific technologies or applications. In the average agreement scores, for example, it can be noticed that a determinant as 'tangibles' $(14,25)$ is more important for mobile television than for mobile news. Regarding 'reliability' (31) people seem to be more sceptical for mobile news, while the determinant 'control (46) seems to result in a higher score for this new mobile application. 'Product knowledge' $(19,35)$, on the other hand, is lower for mobile television. With an $\mathrm{R}^{2}$ ranging between .503 and .795 for the earlier adopters and early majority, these 47 determinant operationalizations certainly seem to be a good set of variables to explain the variance in the dependent variable 'adoption intention'. Even for the later adopter segments this $\mathrm{R}^{2}$ still ranges between .34 and .42 .

Summarizing, for both technological innovations, this set of attitudinal determinant statements explains adoption intentions quite well, but there remain many differences in the significant determinants for the different innovations and adopter segments. 'Compatibility' (39), for example, is only significant for the mobile television's innovators, not for mobile news. Also 'cost' (1) is only significant in the mobile television case (laggards). Furthermore, 'trialability' (41) is significant in both cases, but not for the same segments. Other determinants such as the perceived impact of adoption on one's 'image' (33) was only significant for mobile news' innovators and laggards. In a nutshell, we can notice many 
differences in attitudes, both when compared over the two cases and over the different adopter segments. However, these differences are extremely valuable to feed more accurate and segment-tailored targeting campaigns and marketing strategies.

The reported results emphasize the need for a product and segment specific approach when studying adoption determinants for ICT innovations, illustrating that some of the original domain-specific assumptions of Rogers' diffusion theory (or other frameworks) seem to be no longer sufficient in our contemporary ICT environment. Domain-specific innovation scales (e.g. Goldsmith \& Hofacker, 1991) seem to be losing their relevance since they assume determinants to be generic for the entire domain of ICT. The discussed results illustrate that this is no longer the case anymore and therefore we make a plea for a more product and segment specific approach when studying ICT acceptance. In addition, this is important not only for adoption and use determinants but also in terms of segment sizes.

The latter refers to the diffusion model forecasting applied (i.e. PSAP, De Marez, 2006) within the two presented use cases illustrating that it would be rather naive to assume one similar single peaked or bell shaped diffusion pattern. Figure 3 illustrates that the distinction between the traditional diffusion segments (innovators up to laggards) remains very valuable, but depending on the product there seems to appear significant deviations from the original fixed segment size assumptions of $2,5 \%$ innovators, $13,5 \%$ early adopters, etc.

<Insert Figure 3>

Figure 3: Forecasted adopter segments for mobile news and mobile television

Hence, in the current digital landscape, differences in segment size as well as determinants for different technologies require a product and segment specific approach when investigating the acceptance of ICT innovations. The question remains whether the proposed framework manages to support such product and segment specific investigation of adoption and use determinants. Despite the ambition to offer a comprehensive framework, it will certainly not allow to explain all variation in innovativeness and adoption. Therefore, additional determinants need to be taken into account. Nonetheless, the proposed framework 
has proven to offer a better psychometric quality than the theoretical ones on which it is based on (diffusion theory, (D)TPB, TAM, etc.). The explanatory power of the framework has been tested in different case studies (3G mobile telephony and digital television, each in three waves) covering a total number of about 6000 respondents (De Marez, 2006). In each of the studies, the framework consisting of 19 determinants proved to have an $\mathrm{R}^{2}$ above .50 , while the other models never crossed the threshold with $\mathrm{R}^{2}$ values ranging between .39 and .46.

Meanwhile the results served as an input for the introduction of $3 G$ mobile telephony and digital television in Flanders, illustrating the framework's value for commercial purposes in terms of targeting its most likely customers (innovators, early adopters, etc.) in a customertailored way. From a managerial-industrial perspective, it provides a measurement and profiling instrument for a better targeting and assessment of adopter segments and their adoption determinants. But this leaves open the question how the same framework can also be employed for targeting the distinctive profiles of (non-)adopters/users of technology.

\subsection{Elaboration for policy purposes: Analysis and profiling of non-adopters}

The need for more profound insights in why people do not adopt and/or use ICT innovations is an important question for policymakers. More specifically, as more people are connected and taking full advantage of new possibilities that are offered via Internet, government cannot ignore those groups that are not connected (yet). Therefore, policymakers should at least take the initiative to set up measures that can help people who risk to be excluded - to enhance their participation in the information society (Rogers, 2001; Selwyn \& Facer, 2007).

With this regard, the measurement and profiling instrument (as described above) was extended towards the right(er) part of Rogers' S-curve, focusing on late majority/laggards or even on non-adopters. This part of the research was commissioned by the Belgian government (Fedict - Federal public agency for ICT). The research approach presented below draws on the experience that the Belgian government has acquired through the 
'Internet for all' project in 2006. The latter was set up in collaboration with Internet service providers, PC manufacturers and retailers. The project entailed the provision of an affordable package deal ( $€ 750$ - $€ 1000)$ to customers, consisting of a PC, an Internet connection plus a training session. It was calculated that the project contributed to almost a quarter of the increase of Internet connections between March 2006 and March 2007.

A critical evaluation of the 'Internet for all' campaign revealed different elements, two of which inspired the presented research approach. The first was merely the confirmation of what could be expected. Not all of the groups in society were equally well served by the campaign. Some buyers preferred to buy better-performing and more expensive equipment whilst for others the packages were too expensive, either because the up-front entry cost was too high or because of the recurrent costs of an Internet connection. The second source of inspiration was an incidental call of a representative of a professional organization for physical therapists who proposed a more targeted campaign towards members of his organization. These two apparently banal observations triggered a reflection that inspired the new policy approach and adjoining research.

The presented approach is articulated around the concept of 'relative utility'. Utility is a concept that is often used in technology acceptance studies. Rogers (2003) incorporates 'relative advantage' as one of the innovation characteristics in his diffusion theory. Davis (1989) places 'perceived usefulness' at the centre of this Technology Acceptance Model, in which perceived usefulness and perceived ease of use are the most important determinants on an individual's adoption decision. According to the Social Cognitive Theory, 'outcome expectations' is a central concept together with 'perceived self-efficacy' (Compeau et al, 1999). In the presented approach, however, the interpretation of the utility concept differs from the definitions of diffusion theory, TAM or SCT. Firstly, utility is defined as all perceived benefits of ICT. Secondly, and most importantly, the perceived utility of using ICT is looked at in relation to the perceived cost for using it. Hence, the notion of 'relative utility' is preferred. In other words, the relative utility of a product is "the perceived increase of utility obtained by 
appropriating a product in relation to all emotional, cognitive and material resources to an individual' (Verdegem, 2009, p. 184).

In contrary to the other case studies presented earlier in this article, the present case study is focused on the elaboration and interpretation of parameters of ICT appropriation. By taking into account both the adoption and use decision, it is our aim to provide input for (policy) measures that would help to stimulate ICT acceptance, i.e. the access to and use of basic ICT infrastructure such as computer and Internet.

Following the relative utility approach, it becomes possible to determine a hypothetical 'turning point' for ICT appropriation, namely the point at which the benefits (of using the computer and Internet at home) will outweigh the costs for appropriating an ICT product. The notion of 'cost' is extended to any effort needed for ICT adoption, which is not only money but also, for example, the time required to acquire skills. By exploring this turning point for certain categories of non-users, policymakers would be able to better target their efforts to stimulate the use of ICT. Consequently, the balance between perceived benefits and perceived costs is likely to differ for different categories of individuals. This is based on the assumption that benefits and costs are similar for homogeneous socio-demographic and socio-economic groups. Homogeneity, in this context, means that people share the same characteristics in terms of the most important resources that determine the use of ICT: access, skills and attitudes (ASA). A specific combination of conditions in terms of access to ICT, skills to master the devices and attitudes towards the technology is called an 'ASA profile'.

On a practical level, in order to set up effective e-inclusion measures, the added value of this method is that groups of individuals with relatively homogeneous ASA profiles can easily be identified and reached by policymakers. Very often they are represented by professional or social organizations that know how to reach them and are willing to collaborate with government. A specific offering can then be proposed to these groups, taking into account the specificities of their ASA profile and their socio-economic background. An additional advantage of this group-based approach is that measures can incorporate the 
influence of the social network of individuals. The latter is of major importance when it comes to ICT acceptance (Bakardjieva, 2005; Stewart, 2007).

The approach draws upon the assumption that members of socio-demographically and socio-economically homogeneous groups yield similar perceptions in terms of access, skills and attitudes towards residential computer and Internet use. This hypothesis was tested by means of a quantitative survey (personal interviews with 184 respondents). The research population was composed by hand of a theoretical sampling, meaning that we selected individuals based on a limited number of characteristics, i.e. variables of which previous research has shown that they are of major importance for (non-)adoption of ICT (e.g. gender, age, level of education, etc.). In the research individuals (non-users) were recruited originating from ten groups, varying from single mothers with children to physical therapists. This resulted in certain prototypical profiles, exemplary for the societal diversity without being representative for the overall population.

In order to map respondents' perceptions of computer and Internet use at home, they were presented with a list of statements. These statements are based on the same nineteen adoption determinants that are mentioned above (see Table 1). A number of these statements aim at obtaining information about the respondents' specific ASA profile: 1) positive or negative attitudes towards computer and Internet at home; 2) the presence or lack of skills and competences towards using ICT and 3) the presence or absence or barriers to access ICT. Other statements serve as measurement scales to gain insights in more generic factors such as, for example, the influence of social networks or marketing strategies of the ICT industry. Table 3 illustrates how the determinants were translated into a questionnaire. Respondents were asked to answer on a 5-point Likert scale (varying from 1: 'I do not agree at alf tot 5: 'I fully agree').

$<$ Insert Table 3>

Based on the answers of the respondents on the statements a K-means Cluster Analysis (SPSS) revealed five distinctive groups of domestic non-users of computer and Internet:

- Incapable refusers; 
- Self-conscious indifferents;

- The willing but incapable;

- Skilled ICT-lovers with limited access;

- Price sensitive pragmatists.

The clusters demonstrate that non-adopters and non-users should not be seen as one generic group. Each profile represents a different combination of the factors investigated, in which each factor carries a different weight. Statistical testing was conclusive about the relationship between the group membership (from theoretical sampling) and the membership of the ASA profiles (Pearson Chi-Square $=p<.01$ ). As such, empirical foundation was found for the assumption that homogeneous groups - in terms of socio-demographic and socioeconomic characteristics - result in generic ASA profiles.

Following upon this research stage, qualitative in-depth interviews and focus group interviews were organized to refine insights of why people do not use computer/Internet at home and to examine which leverages could lift them over the turning point between non-use and use. The results of both research stages show the advantage of the approach proposed and offers the opportunity for policymakers to set up measures to stimulate later adopters to ICT appropriation. These measures could be more effective as they are based on strategies of segmentation and differentiation, taking into account the different profiles of these individuals. In addition, the elaboration of adoption and use determinants is necessary to gain insight in a group of individuals that are often ignored in innovation research.

\section{Discussion}

\subsection{Conclusions}

The research presented clearly shows the need for a thorough understanding of user attitudes and preferences towards ICT acceptance. As more technological innovations are introduced in rapid succession and an increased number of those innovations is failing, profound insights in the determinants towards adoption and use become more important. To 
amass this knowledge is important for both public and private interests as Burgelman (2000, p. 236) states: "Consumer research has shown that knowledge about the user tends to be limited ... It is quite self-evident that both social and commercial policies will benefit from accurate insight into the different parameters determining the success (acceptance and use) of these technologies according to a user's point of view." Therefore, the theoretical reconsiderations raised within this article - as well as their empirical application - could provide both ICT managers and policymakers with useful input in support of their innovation strategies. As a matter of fact, the development of an information society for all serves both commercial as social purposes.

In the literature section of this article, a brief overview is presented of research into technology acceptance. A lot of studies still start from the innovation characteristics of Rogers' diffusion theory. Other theoretical models - including frameworks originating from social psychology and other disciplines - have broadened the scope of ICT adoption research. More specifically, attitudinal determinants have come to the foreground. Although this extension has lead to a more elaborated and theoretically founded field in which ICT innovations are studied, a lack of overview seems to exist when it comes to the decision which parameters need to be included in empirical research. As a consequence, meta models such as UTAUT gain in importance. Comparable to UTAUT, an integrated and comprehensive framework is presented within this article. This approach starts from a common set of adoption determinants that have been extended and adapted during different research tracks. The result is a measurement instrument (as a translation of nineteen key determinants, corresponding with innovation related characteristics, adopter related characteristics as well as the impact of marketing strategy). The empirical part of this article briefly illustrates the application of the framework in two case studies containing both an exercise of broadening and deepening of the set of ICT acceptance determinants. 


\subsection{Recommendations}

The framework presented within this article sets the goal to contribute to technology acceptance research by providing a comprehensive model, although it consists of a limited number of adoption and use determinants. This instrument allows to support both ICT managers as policymakers with their innovation strategies, starting from a common framework. The added value of the framework is illustrated below by indicating how our research results enable it to formulate recommendations in profit of ICT managers as well as policymakers. By doing this, it is also shown to what extent we manage to fulfill the goals that we have set for ourselves with the presented framework.

Firstly, one of the objectives of the framework is to (better) support research that focuses simultaneously on the adoption and use of new technologies. The measurement instrument allows to distinguish between the most important adoption determinants. In this regard, the presented list of nineteen determinants incorporates the major innovation characteristics as originally coined by Rogers (2003). But, on the other hand, our list also takes into account attitudinal determinants that enable to accurately estimate which arguments (attitudes) will most probably do their job in persuading the first category of users to adopt the innovation. In the empirical part, it has been discussed which determinants were more significant for innovators and early adopters in both the mobile television and mobile news study. This provides ICT managers with important knowledge on how to bring their innovations on the market (for the product itself but also regarding the introduction strategy). In addition, we stressed that the adoption of new technologies may not be sufficient. Therefore, in the empirical section it was illustrated how policymakers also could benefit from this framework as insights in attitudes need to be combined with perceptions regarding skills and access. More specifically, for later adopters it is important that they have the necessary competencies and capabilities at their disposal in order to be able to use the innovations. This is an important recommendation in profit of policymakers regarding their digital divide policies. 
Secondly, it has been argued that innovation strategies may not be (just) duplicated for a range of new technologies. ICT managers should be aware that there are some important differences when it comes to the adoption of different technologies (e.g. mobile television versus mobile news applications, as illustrated within this article). As it was shown in the empirical part, the presented measurement instrument allows to assess the most important conditions for technology acceptance for different technologies/applications. Figure 3 is a clear illustration of this. In addition, policymakers can also profit from an instrument that is applicable for different innovations. More specifically, policy measures or campaigns that aim to bridge the digital divide should have a specific focus, depending on the particular technology that is the subject of these measures/campaigns. Later adopters or non-users of digital television, for instance, may have different profiles (and consequently different aspects that need to be addressed) in comparison with later adopters/non-users of the Internet.

Thirdly, an important contribution of our framework is that it should manage to differentiate between distinguished segments of the population (both within earlier and later adopters). We have argued that a 'one size fits all' approach may no longer be appropriate, especially in our fast evolving ICT landscape. The presented measurement instrument does not only allows to detect different profiles of potential adopters. It also provides valuable input for industry managers about which profiles should be targeted with a specific communication in order to persuade them to adopt the technology. In the empirical part, it was illustrated that the traditional categorization of adopters by Rogers (2003) is no longer tenable. Therefore, there is a need for an approach that allows a more accurate profiling. The analysis on mobile television and mobile news applications clearly illustrates how the framework could help on this. An important remark is also that ICT managers often focus on the innovative segments of the population. For industrial but also for social goals, however, this should be extended to later adopters (or even non-adopters) as well. For the long-term sustainability of their ICT products, businesses should develop innovations that can be adopted and used by all groups in society. The latter is also an important responsibility of policymakers. The public sector should at least take the initiative to prevent that new digital divides may arise. In the empirical 
analysis on computer and Internet acceptance, we managed to differentiate between five profiles of non-adopters/users. Policymakers could profit from this by developing specific measures or campaigns that take into account the specific characteristics of each sub group. One group would benefit from actions that support them to acquire ICT skills, whilst for other lower access barriers would be the main objective.

Lastly, the differentiation between distinguished profiles of adopters and non-adopters of new technologies is an important goal of our comprehensive framework. As it has been discussed above, these strategies of segmentation are indispensable for setting up more targeted introduction campaigns. Innovation managers would benefit from our approach as they would have a more accurate view on the different profiles of adopters and, consequently, how they should be reached in order to stimulate adoption of the innovations. An example is that focusing on image/prestige determinants would be more effective for innovators, while relative advantage is an aspect that is more important for groups belonging to early majority. Our empirical analysis shows that this is also valuable knowledge in profit of policymakers. More specifically, in the case of acceptance of computer and Internet, we learned that groups labeled as 'incapable refusers' would benefit from different campaigns or actions in comparison to people that below to the group of 'self-conscious indifferents'. As policymakers aim to persuade these distinguished groups to become computer and Internet users, tailor-made campaigns and actions should be set up and should be based on in-depth insights on the segments.

\subsection{Future research directions}

Future research efforts should critically evaluate existing methods and frameworks that are being applied in user-centric research projects. Established techniques often start from a cross-sectional approach, meaning that user attitudes of (sub) groups of the population are investigated on a single basis and on a specific point of time. In order to involve more accurately user needs and expectations in the appropriation process of new communication technologies, user requirements should be examined on a continual basis. This is also 
influenced by the rapidly evolving ICT landscape in which new applications and features succeed at an increasing speed. In addition, as there may emerge more fragmented (new) media audiences, techniques of segmentation and differentiation may gain in importance. More specifically, an individual may vary from being a non-user of one application/service to a heavy user of another application/service, so appropriate methodologies should be able to tackle this.

The methodologies themselves should also be critically reviewed: most of the applied techniques are based on self-reporting. As this has been largely criticized, we should be prepared to experiment with and/or combine existing methodologies with 'new' methods such as contextual inquiry, different forms of ethnography, panel studies (such as e.g. living labs). This holds particularly when we perceive technology acceptance as not only being determined by attitudinal aspects but also by skills that are necessary to productively engage with applications (see the second case study). Especially in the case of investigating people's skills to master the devices, traditional inquiry methods are no longer sufficient and need absolutely to be combined with observational and related techniques.

The scope of future research activities should be broadened by no longer exclusively focusing on attitudinal aspects as such in the technology acceptance process. User attitudes and needs as well as customer expectations continue to be crucial aspects, however, they should be studied in relation to (other) normative beliefs (e.g. peer and social network influence) and control beliefs (e.g. cost-related aspects, the need for requisite knowledge, etc.). The dynamic interplay between access, skills and attitudes should also be taken in account. The latter refers to the (perceived) added value that may have a decisive impact on these aspects.

Last but not least, the measurement instrument (including the determinants) would greatly benefit from extensive validation in the future, both in terms of the research results and in terms of the recommendations that can be drawn from them. The presented framework is comprehensive but simultaneously allows an accurate level of decomposition in the context of ICT acceptance. In addition, it has been applied in research projects that aim 
to better targeting specific segments of the population, both in a commercial/market and a social/policy context. Furthermore, based on these results campaigns have been set up. Future research activities should also aim to measure the impact of approaches that has been based on the framework. This could be organized by comparing a group of respondents that have been targeted by specific actions, and on the other hand, a control group that not have been reached by such tailored measures. Such an approach would allow not only to investigate the methodological results of the approach but also the impact in practice.

\section{References}

Ajzen, I. (1991). The theory of planned behavior. Organizational Behavior and Human Decision Processes, 50(2), 179-211.

Al-Somali, S.A., Gholami, R. \& Clegg, B. (2009). An investigation into the acceptance of online banking in Saudi Arabia. Technovation, 29(2), 130-141.

Atkin, J.A., Neuendorf, K., Jeffers, L.W. \& Skalski, P. (2003). Predictors of audience interest in adopting digital television. The Journal of Media Economics, 16(3) 159-173.

Bakardjieva, M. (2005). Internet society: The internet in everyday life. London \& Thousand Oaks: Sage.

Bobbit, M., \& Dabholkar, P. (2001). Integrating attitudinal theories to understand and predict use of technology-based self service. International Journal of Service Industry Management, 12(5), 423-450.

Bouwman, H. \& De Jong, A. (1996). Predicting consumer adoption of information technologies. In N.W. Jankowski \& L. Hanssen (Eds.) Contours of multimedia: Recent technological, theoretical and empirical developments (pp. 160-170). London: Libbey.

Bouwman, H., van Dijk, J., Van Den Hooff, B. \& Van De Wijngaert, L. (2002). ICT in organisaties. Adoptie, implementatie, gebruik en effecten. Amsterdam: Boom.

Brown, S.A. \& Venkatesh, V. (2005). Model of adoption of technology in the household: A baseline model test and extension incorporating household life cycle. MIS Quarterly, 29(3), 399-426.

Burgelman, J.C. (2000). Innovation of communication technologies: Some general lessons for the future from the pas. In: Cammaerts, B. \& Burgelman, J.C. (ed.) Beyond competition: Broadening the scope of telecommunications policy (229-238). Brussels: VUB Press.

Busselle, R., Reagan, J., Pinkleton, B. \& Jackson, K. (1999). Factors affecting internet use in a saturated-access population. Telematics and Informatics, 16(1-2), 45-58.

Cestre, G. \& Darmon, R.Y. (1998). Assessing consumer preferences in the context of new product diffusion. International Journal of Research in Marketing, 15(2), 123-135.

Chan-Olmsted, S.M. \& Gershon, R.A. (2001). Telecommunications marketing. In R.A. Gershon (Eds.) Telecommunications management. Industry structures and planning strategies (pp. 281-304). New Jersey: Lawrence Erlbaum Associates.

Chang, M.K. \& Cheung, W. (2001). Determinants of the intention to use internet/WWW at work: A confirmatory study. Information and Management, 39(1), 1-14.

Chaudhuri, A., Flamm, K.S. \& Horrigan, J. (2005). An analysis of the determinants of internet access. Telecommunications Policy, 29(9-10), 731-755. 
Chen, L.D., Gillenson, M.L. \& Sherrel, D.L. (2002). Enticing online consumers: An extended technology acceptance perspective. Information and Management, 39(8), 705-719.

Chen, J.V., Yen, D.C. \& Chen, K. (2009). The acceptance and diffusion of the innovative smart phone use : A case study of a delivery service company in logistics. Information \& Management, 46(4), 241-248

Chesbourgh, H.W. (2003). Open innovation: The new imperative for creating and profiting from technology. Boston: Harvard Business School Press.

Chesbourgh, H.W., Vanhaverbeke, W. \& West, J. (2006). Open innovation: Researching a new paradigm. Oxford: Oxford University Press.

Choi, H., Choi, M., Kim, J. \& Yu, H. (2003). An empirical study on the adoption of information appliances with a focus on interactive TV. Telematics and Informatics, 20(2), 161-183.

Compeau, D., Higgins, C. \& Huff, S. (1999). Social cognitive theory and individual reactions to computing Technology: A longitudinal study. MIS Quarterly, 23(2), 145-158.

Davis, F.D. (1986). A technology acceptance model for empirically testing new end-user information systems: Theory and results. Unpublished PhD dissertation, Cambridge: MIT Sloan Management School.

Davis, F.D. (1989). Perceived usefulness, perceived ease of use and user acceptance of information technology. MIS Quarterly, 13(3), 319-340.

De Marez, L., Verleye, G. (2004a). ICT-innovations today: Making traditional diffusion patterns obsolete, and preliminary insight of increased importance. Telematics and Informatics, 21(3), 235-260.

De Marez, L., Verleye, G. (2004b). Innovation diffusion: The need for more accurate consumer insight. Illustration of the PSAP-scale as a segmentation instrument. The Journal of Targeting, Measurement and Analysis for Marketing, 13(1), 32-49.

De Marez, L. (2006). Diffusie van ICT-innovaties: Accurater gebruikersinzicht voor betere introductie-strategieën. Unpublished PhD dissertation, Department of Communication Studies, Ghent University.

Dickerson, M.D. \& Gentry, J.W. (1983). Characteristics of adopters and non-adopters of home computers. The Journal of Consumer Research, 10(2), 225-235.

Dickinger, A., Arami, M. \& Meyer, D. (2008). The role of perceived enjoyment and social norm in the adoption of technology with network externalities. European Journal of Information Systems, 17(1), 4-11.

Dowling, G.R. (1999). Consumer innovativeness. In P.E. Earl \& S. Kemp (Eds.) The Elgar companion to consumer research and economic psychology (pp. 111-115), Cheltenham: Elgar.

Easingwood, C.J. \& Lunn, S.O. (1992). Diffusion paths in a high-tech environment - Clusters and commonalities. R\&D Management, 22(1), 69-80.

Eastin, M.S. (2002). Diffusion of e-commerce: An analysis of the adoption of four ecommerce activities. Telematics and Informatics, 19(3), 251-267.

Eriksson, K. \& Nilsson, D. (2007). Determinants of the continued use of self-service technology: The case of Internet banking. Technovation, 27(4), 159-167.

Fishbein, M.A. (1967). Readings in attitude theory and measurement. New York: Wiley.

Fishbein, M.A. \& Ajzen, I. (1975). Belief, attitude, intention and behavior: An introduction to theory and research. Reading MA: Addison-Wesley.

Frambach, R.T. \& Hillebrand, B. (1994). Diffusietheorie: Overzicht, kritiek en implicaties. Tijdschrift voor Marketing, 28(12), 37-42.

Frambach, R.T. \& Schillewaert, N. (2002). Organizational innovation adoption. A multi-level framework of determinants and opportunities for future research. Journal of Business Research, 55(2), 163-176.

Gatignon, H. \& Robertson, T.S. (1989). Diffusion of innovation. EIASM White Paper, Belgium, Brussels.

Goldsmith, R.E. \& Hofacker, C.F. (1991). Measuring consumer innovativeness. Journal of the Academy of Marketing Science, 19(3), 201-221.

Gunkel, D.J. (2003). Second thoughts: toward a critique of the digital divide. New Media and Society, 5(4), 499-522. 
Hadjimanolis, A. (2003). The barriers approach to innovation. In: Shavinina, L.V. (ed.) The handbook of innovation (pp. 559-573). Oxford, UK: Pergamon, Elsevier.

Heres, J., Mante-Meijer, E. \& Pires, D. (2004). Factors influencing the adoption of broadband mobile internet. In E. Mante-Meijer \& L. Klamer (Eds.) ICT capabilities in action: What people do. Cost Action 269, Brussels. EUR 21637.

Hernandez, B., Jiménez, J. \& Martín, M.J. (2008). Extending the technology acceptance model to include the IT decision-maker: A study of business management software. Technovation, 28(3), 112-121.

Holak, S.L. \& Lehmann, D.R. (1990). Purchase intentions and the dimensions of innovation: An exploratory model. Journal of Product Innovation Management, 7(1), 59-73.

Karahanna, E., Straub, D.W. \& Chervany, N.L. (1999). Information technology adoption across time: A cross-sectional comparison of pre-adoption and post-adoption beliefs. MIS Quarterly, 23(2), 183-213.

Karahanna, E., Agarwal, R. \& Angst, C.M. (2006). Reconceptualizing compatibility beliefs in technology acceptance research. MIS Quarterly, 30(4), 781-804.

Lettl, C., Herstatt, C. \& Gemuenden, H.G. (2006). Learning from users for radical innovation. International Journal of Technology Management, 33(1), 25-45.

Leung, L. (1998). Lifestyles and the use of new media technology in urban China. Telecommunications Policy, 22(9) 781-790.

Liao, H.-L. \& Lu, H.-P. (2008). The role of experience and innovation characteristics in the adoption and continued use of e-learning websites. Computers \& Education, 51(4), 14051416.

Lievrouw, L.A. (2006). New media design and development: Diffusion of innovations versus social shaping of technology. In L.A. Lievrouw \& S. Livingstone (Eds.) The handbook of new media (updated student version) (pp. 246-265). London \& New York: Sage Publications.

$\mathrm{Li}, \mathrm{S} . \mathrm{S}$. (2004). Examining the factors that influence the intentions to adopt internet shopping and cable television in Taiwan. New Media and Society, 6(2), 173-193.

Lin, C.A. (1998). Exploring personal computer adoption dynamics. Journal of Broadcasting and Electronic Media, 42(1), 95-112.

Lin, C.A. (2003). An interactive communication technology adoption model. Communication Theory, 3(4), 345-365.

Lu, J., Liu, C., Yu, C.-H. \& Wang, K. (2008). Determinants of accepting wireless mobile data services in China. Information \& Management, 45(1), 52-64.

Milner, H. (2006). The digital divide: The role of political institutions in technology diffusion. Comparative Political Studies, 39(2), 176-199.

Moore, G.C. \& Benbasat, I. (1991). Development of an instrument to measure the perceptions of adopting an information technology innovation. Information Systems Research, 2(3), 192-222.

Moreau, C.P., Lehmann, D.R. \& Markman, A.B. (2001). Entrenched knowledge structures and consumer response to new products. Journal of Marketing Research, 28, 14-29.

Mudd, S. (1990). The place of innovativeness in models of the adoption process: An integrative review. Technovation, 10(2), 119-136.

Mundorf, N. \& Westin, S. (1996). Adoption of information technology: Contributing factors. In R.R. Dholakia, N. Mundorf \& N. Dholakia (Eds.) New infotainment technologies in the home. Demand-driven perspectives (pp. 157-172). New Jersey: Lawrence Erlbaum Associates.

Neuendorf, K., Atkin, D. \& Jeffres, L. (1998). Understanding adopters of audio information innovations. Journal of Broadcasting and Electronic Media, 42(1), 80-94.

Norris, P. (2001). Digital divide, civic engagement, information poverty and the internet worldwide. Cambrige: Cambridge University Press.

Oh, K.-Y., Cruickshank, D. \& Anderson, A.R. (2009). The adoption of e-trade innovations by Korean small and medium sized firms. Technovation, 29(2), 110-121.

Parasuraman, A. \& Colby, C.L. (2001). Techno-reading marketing: How and why your customers adopt technology. New York: Free Press. 
Plouffe, C.R., Vandenbosch, M. \& Hulland, J. (2001). Intermediating technologies and multigroup adoption: A comparison of consumer and merchant adoption intentions towards a new electronic payment system. Journal of Product Innovation Management, 18(2), 65-81.

Premkumar, G. \& Bhattacherjee, A. (2008). Explaining information technology usage: A test of competing models. Omega, 36(1), 64-75.

Roe, K. \& Broos, A. (2005). Marginality in the information age: The socio-demographics of computers disquietude. A short research note. Communications: the European Journal of Communication, 30(1), 91-96.

Rogers, E.M. (2003). Diffusion of innovations (5th ed.). New York; The Free Press.

Rogers, E.M. (2001). The digital divide. Convergence: The International Journal of Research into New Media Technologies, 7(4), 96-111.

Schepers, J. \& Wetzels, M. (2007). A meta-analysis of the technology acceptance model: Investigating subjective norm and moderation effects. Information \& Management, 44(1), 90-103.

Selwyn, N. (2004). Reconsidering political and popular understandings of the digital divide. New Media and Society, 6(3), 341-362.

Selwyn, N. (2006). Digital division or digital decision? A study of non-users and low-users of computers. Poetics, 34(4-5), 273-292.

Selwyn, N., Facer, K. (2007). Beyond the digital divide: Rethinking digital inclusion for the 21st century. Bristol: FutureLab.

Steenkamp, J.-B.E.M., Gielens, K. (2003). Consumer and market drivers of the trial probability of new consumer packaged goods. Journal of Consumer Research, 30, 368384.

Stewart, J. (2007). Local experts in the domestication of information and communication technologies. Information, Communication and Society, 10(4), 547-569.

Sun, Y., Bhattacherjee, A. \& Ma, Q. (2009). Extending technology usage to work settings: The role of perceived work compatibility in ERP implementation. Information \& Management, 46(6), 351-356.

Talukdar, D., Sudhir, L. \& Ainslie, A. (2002). Investigating new product diffusion across products and countries. Marketing Science, 21(1), 97-114.

Taylor, S. \& Todd, P. (1995). Decomposition and crossover effects in the theory of planned behavior: A study of consumer adoption intentions. International Journal of Research in Marketing, 12(2), 137-155.

Teo, T., Lee, C.B. \& Chai, C.S. (2008). Understanding pre-service teachers' computer attitudes: Applying and extending the technology acceptance model. Journal of ComputerMediated Communication, 24(2), 128-143.

Trkman, P., Blazic, B.J. \& Turk, T. (2008). Factors of broadband development and the design of a strategic policy framework. Telecommunications Policy, 32(2) 101-115.

Turel, O., Serenko, A. \& Bontis, N. (2010). User acceptance of hedonic digital artifacts: A theory of consumption values perspective. Information \& Management, 47(1), 53-59.

van Dijk, J. (2005). The deepening divide: Inequality in the information society. London \& New York: Sage Publications.

van Dijk, J. \& Hacker, K. (2003). The digital divide as a complex and dynamic phenomenon. The Information Society, 19(4), 315-326.

Van Slyke, C., Ilie, V., Lou, H. \& Stafford, T. (2007). Perceived critical mass and the adoption of a communication technology. European Journal of Information Systems, 16(3), 270283.

Verdegem, P. (2009). De digitale kloof en/in e-government: Uitdagingen voor de overhead in de informatiemaatschappij. Unpublished PhD dissertation, Department of Communication Studies, Ghent University.

Venkatesh, V. (2000). Determinants of perceived ease of use: Integrating control, intrinsic motivation, and emotion into the technology acceptance model. Information Systems Research, 11(4), 342-365. 
Venkatesh, V. (2006). Where to go from here? Thoughts on future directions for research on individual-level technology adoption with a focus on decision making. Decision Sciences, 37(4), 497-518.

Venkatesh, V. \& Brown, S.A. (2001). A longitudinal investigation of personal computers in homes: Adoption determinants and emerging challenges. MIS Quarterly, 25(1), 71-102.

Venkatesh, V., Morris, M.G., Davis, G.B. \& Davis, F.D. (2003). User acceptance of information technology: Toward a unified view. MIS Quarterly, 27(3), 425-478.

Veryzer, R. (1998). Key factors affecting customer evaluation of discontinuous new products. Journal of Product Innovation Management, 15(2), 136-150.

Wang, H.-C., Pallister, J.G., Foxall, G.R. (2006). Innovativeness and involvement as determinants of website loyalty: II Determinants of customer loyalty in B2C e-commerce. Technovation, 26(12), 1366-1373.

Warschauer, M. (2003). Technology and social inclusion: Rethinking the digital divide. Cambridge: MIT Press.

Wei, R. (2001). From luxury to utility: A longitudinal analysis of cell phone laggards. Journalism and Mass Communication Quarterly, 78(4), 702-719.

Williams, M.D., Dwivedi, Y.K., Lal, B. \& Schwarz, A. (2009). Contemporary trends and issues in IT adoption and diffusion research. Journal of Information Technology, 24(1), 1-10.

Wirth, W., von Pape, T. \& Karnowski, V. (2008). An integrative model of mobile phone appropriation. Journal of Computer-Mediated Communication, 13(3), 593-617.

Woolgar, S. (1996). Technologies as cultural artefacts. In W.H. Dutton (Eds.) Information and communication technologies: Visions and realities (pp. 87-101). Oxford: Oxford University Press.

Wu, J.H. \& Wang, S.-C. (2005). What drives mobile commerce? An empirical validation of the revised technology acceptance model. Information \& Management, 42(5), 719-729.

$\mathrm{Wu}$, J. \& Lederer, A. (2009). A meta-analysis of the role of environment-based voluntariness in information technology acceptance. MIS Quarterly, 33(2), 419-432.

Wyatt, S. (2005). Non-users also matter: The construction of users and non-users of the internet. In N. Oudshoorn \& T. Pinch (Eds.) How users matter. The co-construction of users and technology (pp. 67-79). Cambridge: MIT Press.

Yu, C.-S. \& Tao, Y.-H. (2009). Understanding business-level innovation technology adoption. Technovation, 29(2), 92-109.

Zhou, Y. (2008). Voluntary adopters versus forced adopters: Integrating the diffusion of innovation theory and the technology acceptance model to study intra-organizational adoption. New Media and Society, 10(3), 475-496.

Ziamou, P. (2002). Commercializing new technologies, consumers' response to a new interface. Journal of Product Innovation Management. 19(5), 365-374. 
<Figure 1>

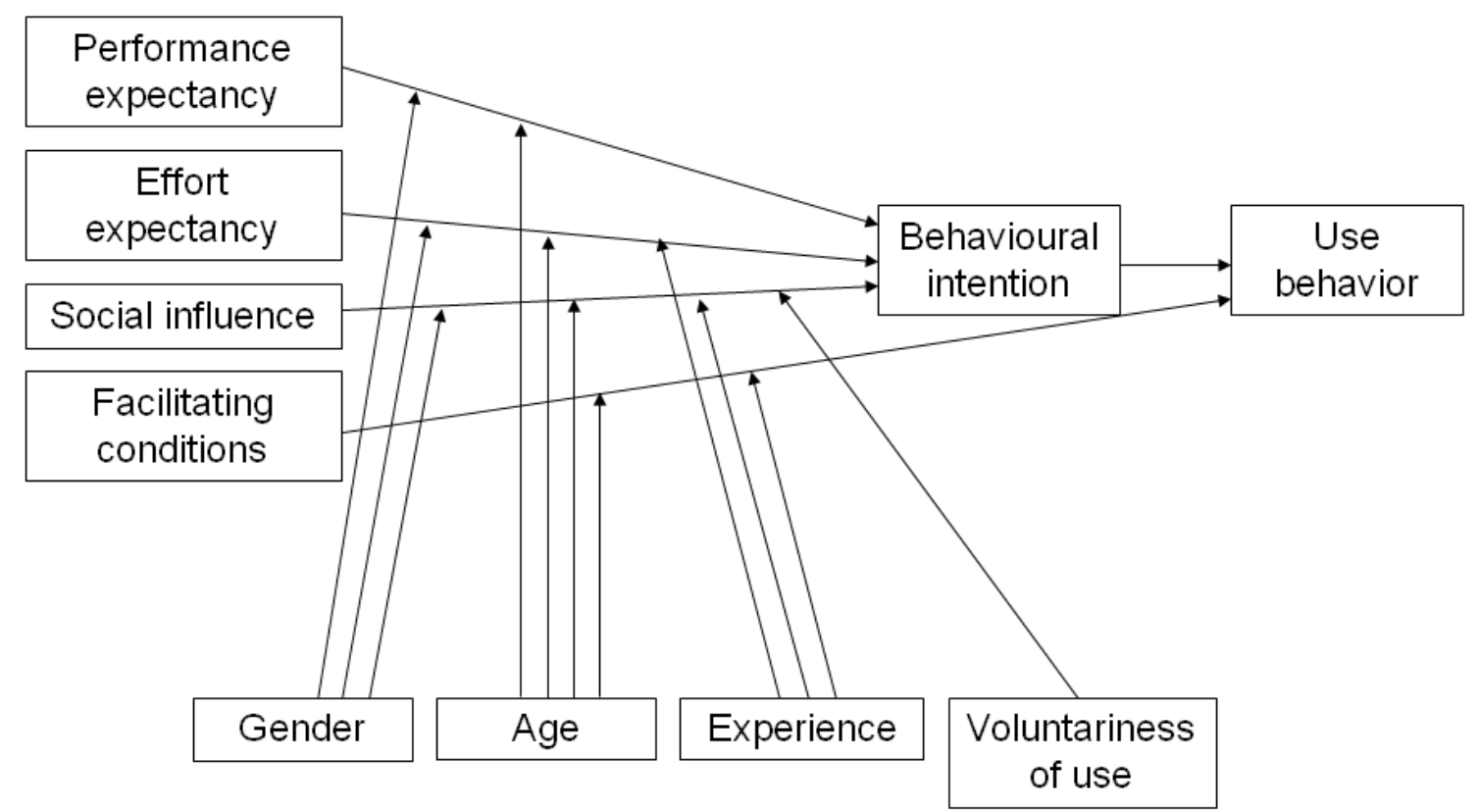


<Figure 2>

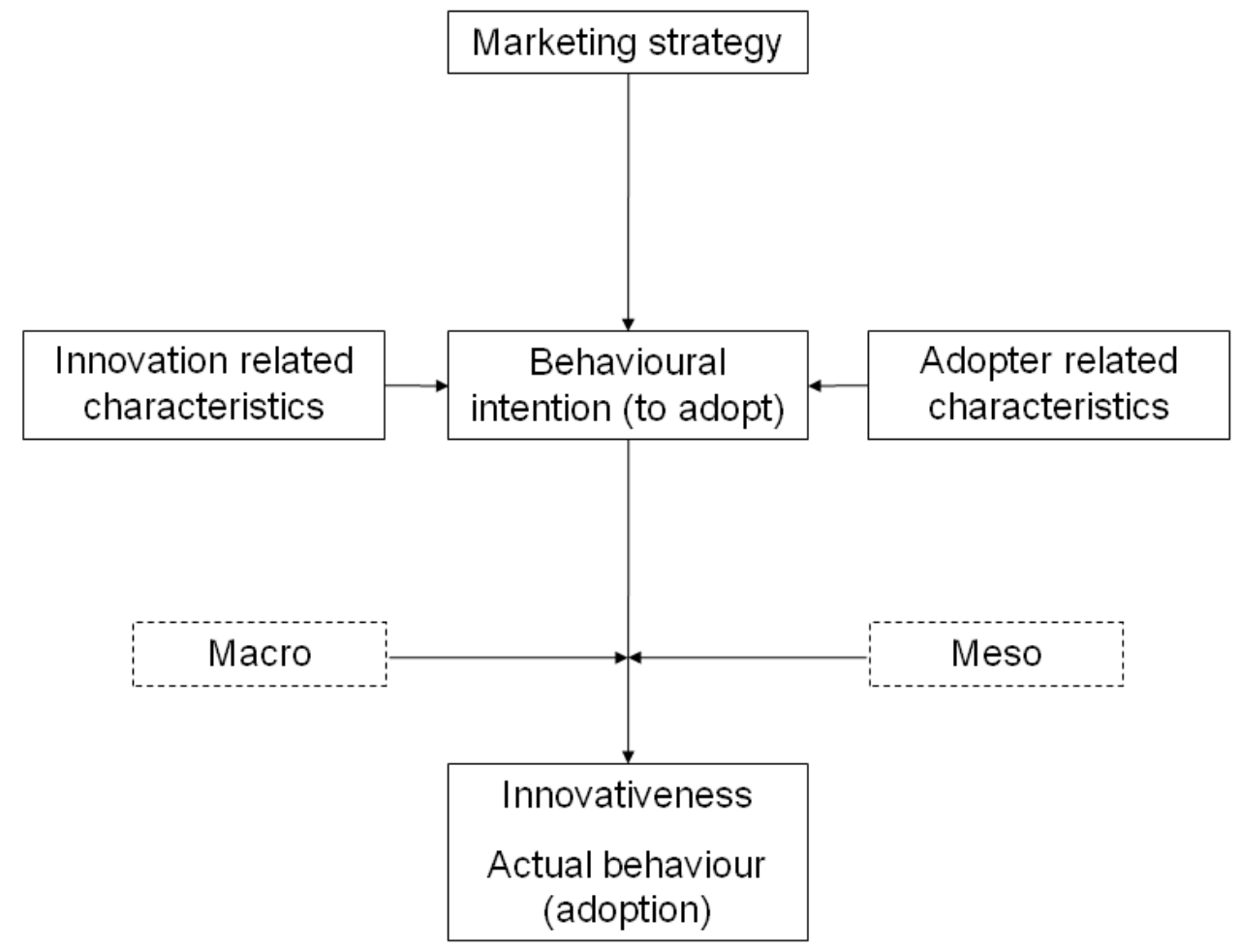


<Figure 3>

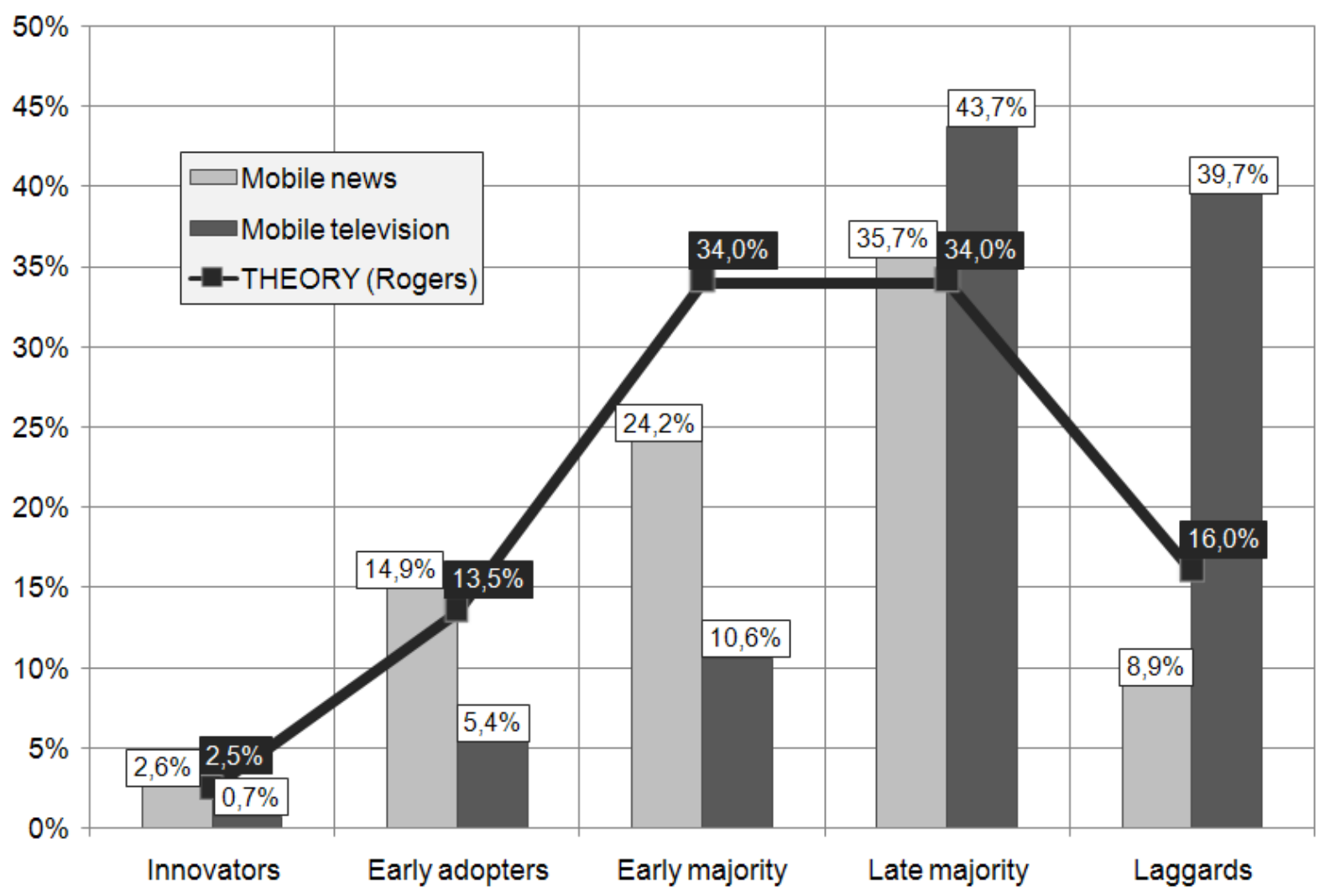


Table 1: Extension of adoption determinants

\begin{tabular}{|c|c|c|}
\hline $\begin{array}{c}\text { ADOPTION } \\
\text { DETERMINANT }\end{array}$ & $\begin{array}{l}\text { ASSUMED RELATION } \\
\text { WITH } \\
\text { INNOVATIVENESS }\end{array}$ & \\
\hline \multicolumn{3}{|c|}{ INNOVATION RELATED CHARACTERISTICS } \\
\hline Compatibility & + & $\begin{array}{l}\text { (Bouwman et al, 2002; Karahanna et al, 2006; } \\
\text { Lin, 2003; Rogers, 2003; Sun et at, 2009) }\end{array}$ \\
\hline Complexity & - & $\begin{array}{l}\text { (Al-Somali et al. 2009; Chang \& Cheung, } \\
\text { 2001; Chen et al, 2002; Hernandez et al, } \\
\text { 2008; Rogers, 2003; Yu \& Tao, 2009) }\end{array}$ \\
\hline Cost & - & $\begin{array}{c}\text { (Brown \& Venkatesh, 2005; Cestre \& Darmon, } \\
\text { 1998; Easingwood \& Lunn, 1992; Heres et al, } \\
\text { 2004; Wu \& Wang, 2005) }\end{array}$ \\
\hline Enjoyment & + & $\begin{array}{c}\text { (Chang \& Cheung, 2001; Choi et al, 2003; } \\
\text { Dickinger et al, 2008; Mundorf \& Westin, } \\
\text { 1996; Turel et al, 2010) }\end{array}$ \\
\hline Observability & + & $\begin{array}{c}\text { (Easingwood \& Lunn, 1992; Liao \& Lu, 2008; } \\
\text { Lin, 2003; Rogers, 2003) }\end{array}$ \\
\hline Relative advantage & + & $\begin{array}{c}\text { (Al-Somali et al. 2009; Eriksson \& Nilsson, } \\
\text { 2007; Hernandez et al, 2008; Karahanna et al, } \\
\text { 1999; Lin, 2003; Oh et al, 2009; Rogers, 2003; } \\
\text { Yu \& Tao, 2009) }\end{array}$ \\
\hline Reliability & + & $\begin{array}{l}\text { (Al-Somali et al. 2009; Dodgson, 2000; Eastin, } \\
\text { 2002; Frambach \& Hildebrand, 1994; Lu et al, } \\
\text { 2008) }\end{array}$ \\
\hline Tangibles & + & $\begin{array}{c}\text { (Chan-Olmsted \& Gershon, 2001; Heres et al, } \\
\text { 2004; Veryzer, 1998) }\end{array}$ \\
\hline Trialability & + & $\begin{array}{l}\text { (Chen et al, 2009; Choi et al, 2003; Heres et } \\
\text { al, 2004; Liao \& Lu, 2008; Rogers, 2003) }\end{array}$ \\
\hline Visibility & + & $\begin{array}{c}\text { (Al-Somali et al. 2009; Heres et al, 2004; } \\
\text { Karahanna et al, 1999; Plouffe et al, 2001; Yu } \\
\text { \& Tao, 2009) }\end{array}$ \\
\hline \multicolumn{3}{|c|}{ ADOPTER RELATED CHARACTERISTICS } \\
\hline Control/Voluntariness & + & $\begin{array}{l}\text { (Al-Somali et al. 2009; Eastin, 2002; } \\
\text { Venkatesh, 2000; Wu \& Lederer, 2009; Zhou, } \\
\text { 2008) }\end{array}$ \\
\hline Image/Prestige & + & $\begin{array}{c}\text { (Moore \& Benbasat, 1991; Plouffe et al, 2001; } \\
\text { Rogers, 2003; Schepers \& Wetzels, 2007; Yu } \\
\text { \& Tao, 2009) }\end{array}$ \\
\hline Innovativeness & + & $\begin{array}{l}\text { (Atkin et al, 2003; Dowling, 1999; Oh et al, } \\
\text { 2009; Li, 2004; Wang et al, 2006) }\end{array}$ \\
\hline (product) Knowledge & + & $\begin{array}{c}\text { (Atkin et al, 2003; Eriksson \& Nilsson, 2007; } \\
\text { Gatignon \& Robertson, 1989; Moreau et al, } \\
\text { 2001) }\end{array}$ \\
\hline Opinion leadership & + & $\begin{array}{l}\text { (Frambach \& Hildebrand, 1994; Lettl et al, } \\
\text { 2006; Lin, 2003; Wirth et al, 2008; Woolgar, } \\
\text { 1996) }\end{array}$ \\
\hline Optimism & + & (Neuendorf et al, 1998; Parasuraman \& Colby, \\
\hline
\end{tabular}




\begin{tabular}{|c|c|c|}
\hline & & 2001; Teo et al, 2008; Wei, 2001) \\
\hline Social influence & + & $\begin{array}{c}\text { (Al-Somali et al. 2009; Karahanna et al, 1999; } \\
\text { Fishbein \& Ajzen, 1975; Taylor \& Todd, 1995; } \\
\text { Yu \& Tao, 2009) }\end{array}$ \\
\hline Willingness to pay & + & $\begin{array}{c}\text { (Brown \& Venkatesh, 2005; Busselle et al, } \\
\text { 1999; Gatignon \& Robertson, 1989; Talukdar } \\
\text { et al, 2002) }\end{array}$ \\
\hline IMPACT OF MARKETING STRATEGY & \\
\hline Marketing (impact) & + & $\begin{array}{c}\text { (Bouwman \& De Jong, 1996; De Marez \& } \\
\text { Verleye, 2004; Gatignon \& Robertson, 1989; } \\
\text { Steenkamp \& Gielens, 2003) }\end{array}$ \\
\hline
\end{tabular}


$<$ Table 2>

Table 2: Operationalization of determinants in 47 Likert statements

(applied to the mobile news/TV cases)

\section{COMPATIBILITY - LIFESTYLE AND PERSONALITY}

7. Consultation of mobile news/TV services fits my lifestyle

39. If I buy a new mobile, it has to be a model that fits my personality

COMPATIBILITY - (TECHNOLOGICAL)

30. I am interested in subscribing to mobile news/TV services. But I would mind if that would imply an investment in a new device

13. Mobile news/TV services are only interesting to me as a part of the subscription on other mobile services

\section{COMPLEXITY/COMFORT LEVEL}

8. I fear that mobile new/TV services application offers different possibilities, which makes It rather complicated

20. The mobile news services application seems very user-friendly to me

29. The mobile news/TV services application offers different possibilities, which makes it rather complicated

\section{CONTROL/SELF-EFFICACY}

46. I have no problem to sort out on myself how mobile news/TV application work and must be installed

COST (RELATIVE ADVANTAGE)

1. Subscription on mobile news/TV services seems expensive to me

5. Mobile news/TV services will probably cost too much for many people

EFFECTIVENESS (RELATIVE ADVANTAGE)

36. Mobile news/TV services will certainly make some things easier for me

ENJOYMENT

4. Mobile news/TV service seems very user friendly to me

IMAGE PRESTIGE

33. Subscribing to mobile news/TV services applications would have a positive impact on my image and social status

38. Subscribing to mobile news/TV services beams out a certain standing

INNOVATIVENESS

6. I think to be among the first to subscribe to such mobile news/TV services

34. Based on what I already knew about the application and what I have learned today, I will certainly search for more information about subscribing to these services

MARKETING STRATEGY

26. If I would subscribe to a mobile news/TV application, it would be important to me that it is provided by a well-known brand

27. If I would consider mobile news/TV adoption, I would first check the ads, brochures and promotions

OBSERVABILITY - RESULT DEMONSTRABILITY / COMMUNICABILITY

24. I am perfectly able to explain the strengths and the weakness of mobile news/TV services to others 


\begin{tabular}{|l|}
\hline OBSERVABILITY - VISIBILITY \\
\hline $\begin{array}{l}\text { 12. One of the nice things of a mobile news/TV application is that it is something to show off with } \\
\text { among friends }\end{array}$ \\
\hline 17. I see many people in my environment who use mobile news/TV services \\
\hline OPINION LEADERSHIP \\
\hline 15. If mo
\end{tabular}

15. If mobile news/TV would be introduced on the market, people in my environment will certainly come to me for advice

\section{OPTIMISM}

44. The fast technological developments are a good thing

45. If you do not want to run behind, adoption of new technologies is necessary

\section{PERCEIVED RISK (FINANCIAL)}

18. I fear that subscribing to a mobile news/TV application would be way above my budget

\section{PERCEIVED RISK (IMPLEMENTATION)}

23. If I would have to use such mobile news/TV applications on my own, I do not think I would manage

\section{PERCEIVED RISK (SOCIAL)}

21. If I would use mobile news/TV services, people in my environment would look odd at me

\section{PRODUCT KNOWLEDGE}

19. I recently send something about mobile news/TV services or recently talked to someone about it

35. I consider myself well-informed about the possibilities and (dis)advantages of mobile news/TV services

\section{RELATIVE ADVANTAGE}

11. The advantages of mobile news/TV services are clearer to me than the disadvantages

40. I do not see where or when to use mobile news/TV services

RELIABILITY

31. I doubt the reliability and proper functioning of the mobile news/TV services application

\section{SOCIAL INFLUENCE}

9. Most people in my environment will certainly be enthusiast about the mobile news/TV application

\section{SOCIAL INFLUENCE - COMPLIANCE}

2. If 'mobile news/TV usage' would be considered as trendy in my environment, I would certainly consider subscribing to it

10. My direct environment will probably expect me to be one of the first to use mobile news/TV services

32. Even if I am interested, I would not subscribe if my environment would be negative about mobile news/TV applications

\section{SOCIAL INFLUENCE - IDENTIFICATION}

47. If I would use mobile news/TV services, it would certainly tell something about me and my personality

\section{SOCIAL INFLUENCE - INTERPERSONAL COMMUNICATIONS}

3. Before subscribing to a mobile news/TV application, I would like the advice of some people 16. Mobile news/TV services will certainly be a topic of discussion among my friends and family 


\begin{tabular}{|l|}
\hline SOCIAL INFLUENCE - NETWORK EXTERNALITIES \\
\hline $\begin{array}{l}\text { 37. I am interested in subscribing to mobile news/TV services, but only if there are sufficient } \\
\text { people in my direct environment doing so. Otherwise, the application would not have much value } \\
\text { to me }\end{array}$ \\
\hline TANGIBLES (RELATIVE ADVANTAGE) \\
\hline $\begin{array}{l}\text { 25. As the mobile news/TV services is presented and testable now it has an attractive design } \\
\text { and style }\end{array}$ \\
\hline $\begin{array}{l}\text { 14. If I would consider buying a new mobile, design would be a very important buying argument } \\
\text { to me }\end{array}$ \\
\hline TRIALABILITY - PHYSICAL \\
\hline 41. I would like to try out mobile news/TV services before subscribing to them \\
\hline TRIALABILITY - VICARIOUS \\
\hline $\begin{array}{l}\text { 28. Before subscribing or adopting mobile news/TV services I prefer to look around for a while } \\
\text { and see how others are experiencing the application }\end{array}$ \\
\hline VOLUNTARINESS \\
\hline $\begin{array}{l}\text { 42. If I would subscribe to mobile news/TV services, it would completely be my own decision. No } \\
\text { one would influence me in making that decision }\end{array}$ \\
\hline WILLINGNESS-TO-PAY \\
\hline 22. Even if it costs a bit more, mobile news/TV is something I really want \\
\hline
\end{tabular}


$<$ Table 3>

Table 3: Operationalization of determinants in 37 Likert statements

(applied to the personal computer and internet acceptance at home case)

ENJOYMENT - Using PC/internet at home seems funny to me **

SOCIAL INFLUENCE - When everyone in my social environment is using PC/internet at home, I will consider starting to use it myself **

COMPLEXITY - PC/internet seems user-friendly to $\mathrm{me}^{\text {** }}$

MARKET STRATEGY - If I would buy a PC/internet, it is important to me that it is supplied by a well-known brand **

COST - Using PC/internet at home seems expensive to me

TANGIBLES - If I would consider buying a PC, its design would be an important argument for buying to me **

IMAGE/PRESTIGE - Using PC/internet at home has a positive impact on my image and social status **

PRODUCT KNOWLEDGE - I consider myself well-informed about the possibilities and (dis)advantages of using PC/internet * *

COMPLEXITY - I fear that using PC/internet at home is rather complicated for me **

OPTIMISM - The fast technological developments are a good thing *

SELF-EFFICACY - I have no problem to sort out how to use PC/internet by myself ${ }^{* *}$

SOCIAL INFLUENCE - Using PC/internet at home is certainly a topic of discussion among my friends and family **

OBSERVABILITY - I am perfectly able to explain the strengths and weaknesses of PC/internet to others **

RELATIVE ADVANTAGE - I do not know when I would use PC/internet at home **

WILLINGNESS-TO-PAY - Even if it costs a bit more, using PC/internet at home is something I really want **

RELIABILITY - I doubt the reliability and proper functioning of using PC/internet at home **

PERCEIVED RISK - If I would have to use PC/internet at home on my own, I do not think I would manage that **

MARKET STRATEGY - If I would consider buying a PC/internet, I would first check the ads, brochures and promotions **

RELATIVE ADVANTAGE - The advantages of using PC/internet at home are more important than the disadvantages for me *

COMPATIBILITY - If I buy a PC, it has to be a model that fits with my personality **

COST - Using PC/internet at home will probably be too expensive for many people *

TRIALABILITY - I would like to try out PC/internet before buying it for myself **

SOCIAL INFLUENCE - I am interested in buying a PC/internet for home, but only if there are enough people in my social environment doing so **

SOCIAL INFLUENCE - If I would use PC/internet at home, it would certainly explain something about me and my personality **

COMPLEXITY - I fear that using PC/internet offers different possibilities, which makes it too complicated to me **

INNOVATIVENESS - Based on what I already know about PC/internet, I will certainly look for more information in order to buy a PC/internet **

OPINION LEADERSHIP - People in my environment will certainly come to me for advice 


\begin{tabular}{|c|}
\hline Concerning the usage of PC/internet ${ }^{* *}$ \\
\hline RELATIVE ADVANTAGE - Using PC/internet at home would make life easier for me ${ }^{* *}$ \\
\hline OPTIMISM - If you do not want to run behind, adoption of new technologies is necessary \\
\hline VOLUNTARINESS - If I would buy a PC/internet, it would completely be my own decision. \\
Nobody can influence that decision
\end{tabular}

${ }^{*}=$ Statistically significant difference $(p<.05)$

${ }^{* *}=$ Statistically significant difference $(p<.01)$ 